\title{
Research for the factors effecting the headache experienced by the health-care personnel in COVID-19 pandemic: A monocentric survey study
}

\author{
COVID-19 pandemisinde görevli sağılk personelinin yaşadığı baş ağrısında etkili faktörlerin \\ araştırılması: Tek merkezli bir anket çalışması
}

\author{
(D) Gülçin HACIBEYOĞLU,' (i) Ayşe Seda EREN, ${ }^{2}$ (I) Şule ARICAN,' (i) Resul YILMAZ,' (i) Ruhiye REISLí, \\ DS Sema TUNCER UZUN ${ }^{2}$
}

\begin{abstract}
Summary
Objectives: The aim of this study is to determine the factors that may be related to the headache experienced by health-care professionals in the coronavirus disease 2019 (COVID-19) pandemic.

Methods: The target population of the study consisted of the health-care professionals working in the COVID-19 pandemic. The questionnaire form consisted of 40 questions. The demographic information of the participants, the presence of contact with the COVID-19 patient, they used which personal protective equipment (PPE) and how often, the effect of the pandemic process on the lifestyle, the presence of visual defects, the effect of the pandemic process on water consumption, the presence of old or de novo headaches, the factors that may affect this headache, and the factors that reduce the pain were questioned in the survey.

Results: A total of 177 health-care professionals participated in the study. About $93.8 \%$ of the participants use masks daily for more than $4 \mathrm{~h}$. About $62.7 \%$ of the participants stated that their water consumption increased on the days when they used PPE. About $72.3 \%$ of the participants reported disruption in sleep patterns, $83.1 \%$ of them reported increase in their stress and anxiety. About $65.5 \%$ of the participants experienced headaches during the pandemic process. They reported that the most likely causes of headache were excessive sweating and difficulty in breathing due to the use of PPE.
\end{abstract}

Conclusion: During the pandemic, a substantial portion of health-care professionals experiences headaches. Besides the physical difficulties caused by the use of PPE, the stress caused by the pandemic process should not be ignored.

Keywords: Headache; pandemic; personal protective equipment.

\section{Özet}

Amaç: Bu çalışmada amaç COVID-19 pandemisinde görevli sağlık personelinin pandemi sürecinde yaşadığı baş ağrısının hangi faktörlere bağıı olabileceğini tespit etmektir.

Gereç ve Yöntem: Çalışmanın evrenini COVID-19 pandemisinde görev alan sağlık personeli oluşturdu. Anket formu 40 adet sorudan oluşturuldu. Ankette katılımcıların demografik bilgileri, COVID-19 hastası ile temas varlığı, hangi kişisel koruyucu ekipmanı hangi sıklıkta kullandığı, pandemi sürecinin yaşam tarzına etkisi, görme kusuru varlığı, pandemi sürecinin su tüketime olan etkisi, eski veya de novo baş ağrısı varlığı, bu ağrıya etkili olabilecek faktörler ve ağrıyı azaltan faktörler sorgulandı.

Bulgular: Çalışmaya 177 sağlık çalışanı katıldı. \%93,8'inin günlük maske kullanımı 4 saatin üzerindedir.Kişisel koruyucu ekipman kullandıkları günlerde katılımcıların \%62,7'si su tüketimlerinin artığını bildirmişlerdir. \%72,3'ü uyku düzeninde bozulma, $\% 83,1^{\prime} i$ stres ve endişelerinde artış bildirmiştir. Katılımcıların \%65,5'i pandemi sürecinde baş ağrısı yaşamıştır. Baş ağrısının muhtemel nedenleri olarak en çok kişisel koruyucu ekipman kullanımına bağlı aşııı terleme ve nefes alıp vermenin zorlaşmasını bildirmişlerdir.

Sonuç: Pandemi sürecinde sağlık çalışanlarının önemli bir bölümü baş ağrısı yaşamaktadır. Baş ağrısı oluşumu üzerinde kişisel koruyucu ekipman kullanımının oluşturduğu fiziksel zorluklar yanında pandemi sürecinin oluşturduğu stres de gözardı edilmemelidir.

Anahtar sözcükler: Baş ağrısı; pandemi; kişisel koruyucu ekipman.

'Department of Anesthesiology and Reanimation, Necmettin Erbakan University, Meram Faculty of Medicine, Konya, Turkey 2Department of Algology, Necmettin Erbakan University, Meram Faculty of Medicine, Konya, Turkey

Submitted (Başvuru tarihi) 02.02.2021 Accepted after revision (Düzeltme sonrası kabul tarihi) 14.06.2021 Available online date (Online yayımlanma tarihi) 03.11.2021

Correspondence: Dr. Gülçin Hacıbeyoğlu. Necmettin Erbakan Üniversitesi Meram Tıp Fakültesi, Anesteziyoloji ve Reanimasyon Anabilim Dalı, Konya, Turkey. Phone: +90 - 505 - 4455498 e-mail: drgulcin81@gmail.com

(c) 2022 Turkish Society of Algology 


\section{Introduction}

Severe acute respiratory diseases were reported from Wuhan City, Hubei Province, China, in late December 2019. In a short time, it was understood that the disease was caused by the severe acute respiratory syndrome coronavirus 2 (SARS-CoV-2) virus and it was named as coronavirus disease 2019 (COVID-19) and declared as a pandemic by the World Health Organization..$^{[1]}$ The first case in our country was reported in mid-March, and the pandemic process started to be managed by taking measures by the Ministry of Health after that date. One of the most important steps among these measures is the use of personal protective equipment (PPE) to protect health-care personnel from contamination. The long-term use of this equipment causes some disturbing results on the person using it. ${ }^{[2]}$ Headache caused by PPE was reported with a rate of $37 \%$ in the SARS epidemic, especially due to the use of N95 mask and protective goggles. ${ }^{[3]}$ It has been known for many years that anxiety, stress, and lifestyle changes are also etiological factors in different types of headache. ${ }^{[4]}$

In this study, the factors, which might cause the headache experienced by health-care professionals who took charge in the COVID-19 pandemic during the pandemic process, especially the share of the negative impact of PPE use and the pandemic process on lifestyle, and the characteristics of the pain, were investigated. We anticipate that the results of the study will contribute to the measures to be taken to reduce the headache frequency experienced by health-care personnel during the pandemic period and to the treatment process.

\section{Material and Methods}

The study was carried out on a monocentric basis in Necmettin Erbakan University Meram Medical Faculty Hospital in line with the principles stated in the Declaration of Helsinki, with the approval of the local ethics committee (Decision No: 20202674). The population of the study consisted of the health-care professionals working in the COVID-19 pandemic. The questionnaire forms were introduced to all participants, the participants were informed about the purpose of the study, and their approvals were obtained. The study was carried out on a voluntary basis. The questionnaire form consisted of 40 questions prepared in accordance with the purpose and scope of the study. Sixteen closed-ended questions, four open-ended questions, and 20 multiple-choice questions were asked. Demographic information of the participants, the presence of contact of the healthcare personnel with the COVID-19 patient, which PPE and how often the participants used, the presence of chronic disease of participants, the effect of the lifestyle of participants and pandemic process on their lifestyle, the presence of visual defects of the participants and the effect of PPE on using goggles, the water consumption of the participants and the effect of the pandemic process on consumption, the presence of de novo headache that occurred before the pandemic process or that occurred during the pandemic process and the factors that may affect this pain, the characteristics of the headache experienced by the participants during the pandemic process, and the factors that reduce pain were questioned with the forms.

Descriptive analysis (percentage, mean \pm standard deviation) was performed for all data using the SPSS 21.0 program. The Chi-square test was used to evaluate the effects of different variables on headache. $p<0.05$ was considered statistically significant.

\section{Results}

In the period that the study was carried out, questionnaires were distributed to 177 people who agreed to participate in the study from 300 healthcare personnel who took charge in the COVID-19 pandemic. About $59 \%$ of the study population was reached. Missing data were not detected in the questionnaire forms and all of them were put into statistical evaluation. One hundred and three (58.2\%) of the participants were male and $74(41.8 \%)$ were female. The occupational distribution of the participants, whose average age is $32.38 \pm 7.36$, is given in Figure 1. Thirty-five (19.8\%) of the participants were working in the intensive care unit, 68 (38.4\%) in the operating room, $26(14.7 \%)$ in the emergency service, and $48(27.1 \%)$ in other services. All of the participants had contact with COVID-19-positive or suspected patients, and all of them used PPE in their departments. The duration that the participants worked in the area with COVID-19-positive or suspected patient care is given in Figure 2. 


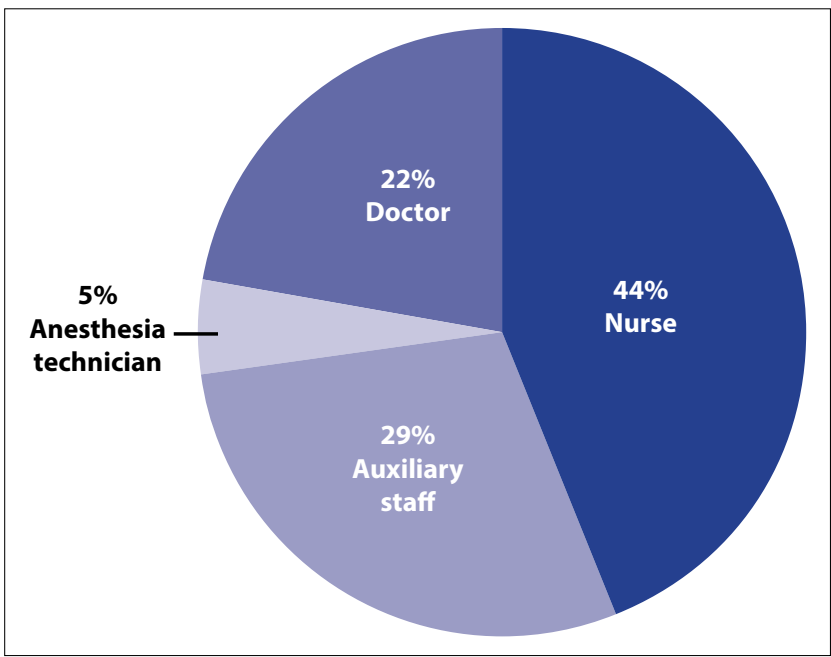

Figure 1. Occupational distribution of the participants.

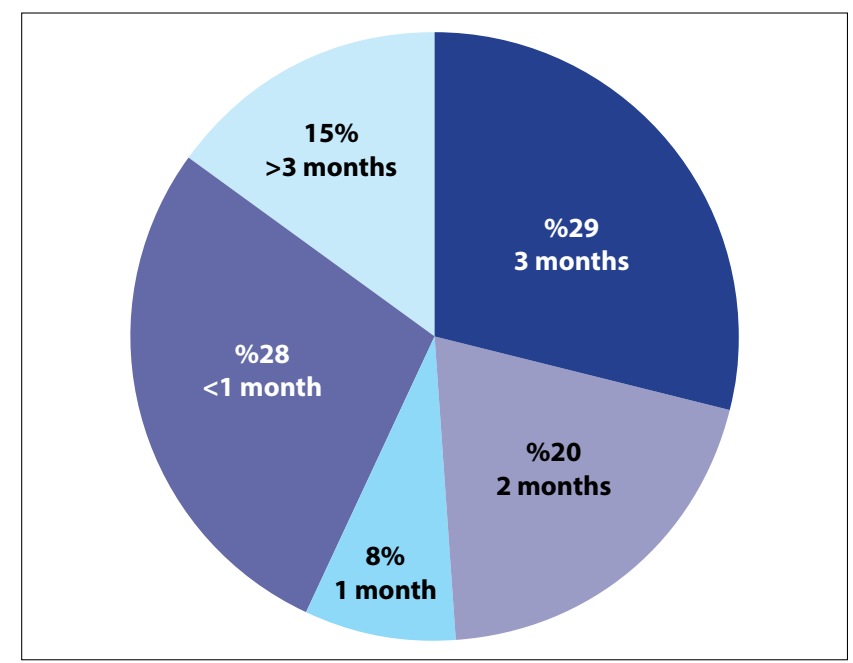

Figure 2. Working duration of participants in COVID services.

One hundred and forty-one (79.7\%) of the participants gave the answer (mask, gloves, protective goggles, face shield, and protective coveralls) to the question of which PPE they use. To the question of "What type of mask did you use?" 15 (8.5\%) of the participants answered only surgical mask, 40 (22.6\%) N95 or FFP2 equivalent mask, and 122 (68.9\%) both. Frequency of PPE use of participants is given in Table 1.

Considering the health backgrounds of the participants, 29 (16.4\%) had a history of chronic disease. The most common accompanying chronic disease was asthma with 9 (5.1\%). Seventy-four (41.8\%) of the participants had a visual defect and 61 (34.4\%) were wearing goggles. Whereas 35 (19.8\%) of the goggles wearers wore their goggles that they use due to their visual defects while wearing PPE, 26 $(14.7 \%)$ of them did not wear.

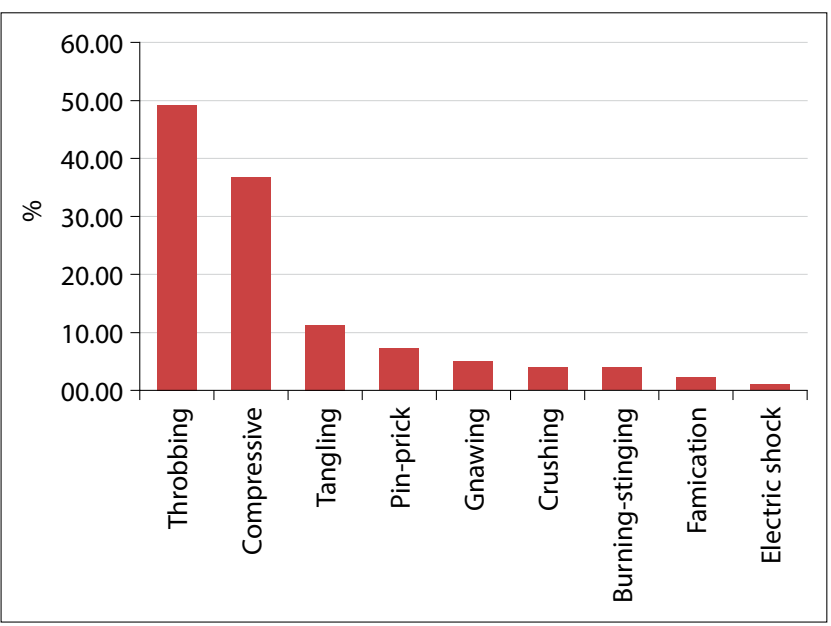

Figure 3. The characteristics of the headache experienced during the pandemic process.

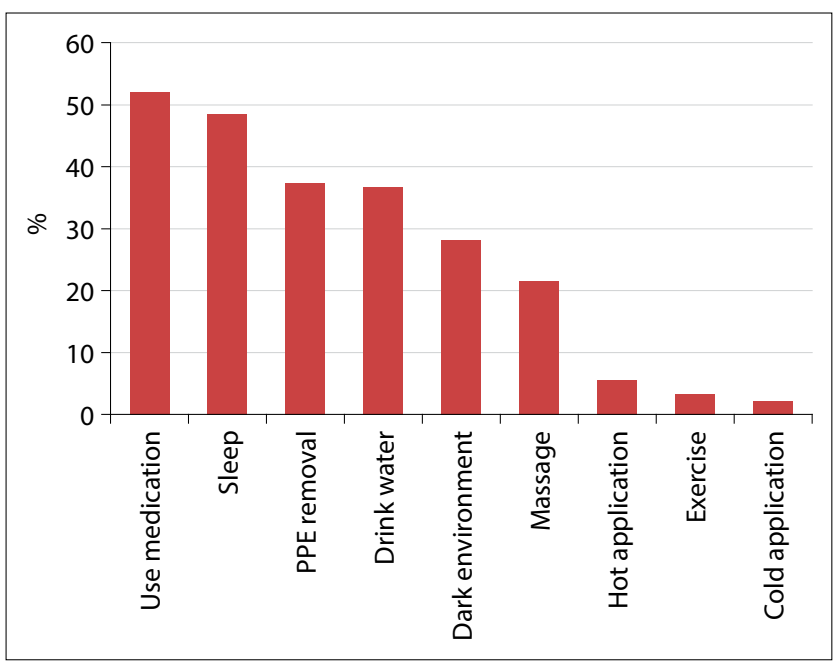

Figure 4. Factors reducing headache of the participants.

When the lifestyle of the participants was questioned, it was determined that 66 (37.3\%) of participants smoke, 8 (4.5\%) of them use alcohol, that 17 (9.6\%) of them consume daily water $<1 \mathrm{~L}, 97(54.8 \%)$ of them $1-2 \mathrm{~L}, 53$ (29.9\%) of them $2-3 \mathrm{~L}$, and $10(5.7 \%)$ of them more than $3 \mathrm{~L}$. It was determined that the daily water consumption of 111 (62.7\%) increased, $32(18.1 \%)$ of them decreased and $34(19.2 \%)$ of them did not change during the days they used PPE. The effects of the pandemic period on the lifestyle of the participants are given in Table 2.

Fifty-five (31.1\%) of the participants answered yes to the question of "Did you have a headache before the pandemic period?" 122 (68.9\%) answered no. Fifty (28.2\%) of those, who had headaches before the pandemic, stated that the frequency and severity of pain increased during the pandemic. Sixty-six $(37.3 \%)$ of the participants answered that they ex- 
Table 1. Frequency of PPE use of participants

\begin{tabular}{|c|c|c|c|c|c|c|}
\hline \multirow[t]{2}{*}{ Frequency of use } & \multicolumn{2}{|l|}{ Mask } & \multicolumn{2}{|c|}{$\begin{array}{l}\text { Goggles and/ } \\
\text { or face shield }\end{array}$} & \multicolumn{2}{|c|}{$\begin{array}{l}\text { Mask+goggles and/ } \\
\text { or face shield+coverall }\end{array}$} \\
\hline & $\mathbf{n}$ & $\%$ & $\mathbf{n}$ & $\%$ & $\mathbf{n}$ & $\%$ \\
\hline \multicolumn{7}{|l|}{ Daily } \\
\hline I did not use & - & - & 4 & 2.3 & 35 & 19.8 \\
\hline$<1 \mathrm{~h}$ & 2 & 1.1 & 13 & 7.3 & 11 & 6.2 \\
\hline $1-4 h$ & 9 & 5.1 & 65 & 36.7 & 33 & 18.6 \\
\hline$>4 \mathrm{~h}$ & 166 & 93.8 & 95 & 53.7 & 98 & 55.4 \\
\hline \multicolumn{7}{|l|}{ Monthly } \\
\hline I did not use & - & - & 12 & 6.8 & 40 & 22.6 \\
\hline $1-6$ days & 17 & 9.6 & 43 & 24.2 & 54 & 30.5 \\
\hline 7-14 days & 28 & 15.8 & 64 & 36.2 & 39 & 22 \\
\hline$>15$ days & 132 & 74.6 & 58 & 32.8 & 44 & 24.9 \\
\hline
\end{tabular}

PPE: Personal protective equipment.

Table 2. The lifestyle of the participants and the effects of the pandemic period

\begin{tabular}{|c|c|c|c|c|c|c|c|c|c|c|}
\hline \multirow[t]{2}{*}{ Answer } & \multicolumn{2}{|c|}{ Smoking } & \multicolumn{2}{|c|}{ Alcohol use } & \multicolumn{2}{|c|}{$\begin{array}{l}\text { Disruption in } \\
\text { sleep pattern }\end{array}$} & \multicolumn{2}{|c|}{$\begin{array}{c}\text { Increase } \\
\text { in stress } \\
\text { and anxiety }\end{array}$} & \multicolumn{2}{|c|}{$\begin{array}{l}\text { Capability } \\
\text { to do sports } \\
\text { and exercise }\end{array}$} \\
\hline & $\mathbf{n}$ & $\%$ & $n$ & $\%$ & n & $\%$ & $\mathbf{n}$ & $\%$ & $n$ & $\%$ \\
\hline Yes & 66 & 37.3 & 8 & 72.3 & 128 & 72.3 & 147 & 83.1 & 33 & 18.6 \\
\hline No & 111 & 62.7 & 169 & 95.5 & 49 & 27.7 & 30 & 16.9 & 144 & 81.4 \\
\hline
\end{tabular}

perienced de novo headaches during the pandemic period. The reasons to which the participants, who have de novo headache or who have an increase in the frequency and severity of the existing headache, attribute this situation, are given in Table 3.

When the characteristics of the pain of 116 (65.5\%) participants, who experienced headache during the pandemic process, were questioned, 74 (41.8\%) participants answered that they had bilateral pain, 30 (16.9\%) of them that they had pain accompanied by nausea and/or vomiting, 67 (37.9\%) of them that they had sensitivity to light and/or sound, $71(40.1 \%)$ of them that they had pain for 1-4 h, 27(15.3\%) for 4-24 $\mathrm{h}, 11(6.2 \%)<1 \mathrm{~h}$, and $7(4 \%)$ more than $24 \mathrm{~h}$. When the characteristics of the pain were questioned, 87 (49.2\%) participants answered that it was "throbbing." The characteristics of the headache experienced by the participants are given in Figure 3. When the participants were asked to evaluate the severity of their headache over 10 points, $19(10.7 \%)$ answered as 4 and below, 97 (54.8\%) answered as 5 and above. Ninety-one (52\%) participants answered yes to the question of "Did you take medication for your headache?" The medication takers answered that $44(24.1 \%)$ of them used nonsteroidal anti-inflammatory, (NSAl) $30(16.9 \%)$ of them used paracetamol, and 17 (9.6\%) of them used both. When the factors reducing headache experienced during the pandemic process were questioned, 91 (52\%) of participants answered as taking medication and 86 (48.6\%) as sleeping (Fig. 4).

When the effects of the duration of use of PPE, the working duration in the COVID service, the presence of visual defects, and the change in daily water consumption on the emergence of de novo headache during the pandemic process and on the increase in the severity of the existing headache were examined, it was found that only the use of masks for more than $4 \mathrm{~h}$ per day and the combined use of masks + goggles/face shield + overalls for $<15$ days were statistically significant ( $p=0.040-p=0.018$ ) (Table 4). 
Table 3. Factors causing increase in headache frequency and severity

\begin{tabular}{|c|c|c|c|c|}
\hline \multirow[t]{2}{*}{$\begin{array}{l}\text { Factors that the participants think as having } \\
\text { an effect on headache }\end{array}$} & \multicolumn{2}{|c|}{$\begin{array}{c}\text { Those who have } \\
\text { headache before } \\
\text { the pandemic period }\end{array}$} & \multicolumn{2}{|c|}{$\begin{array}{c}\text { Those who have de novo } \\
\text { headache during } \\
\text { pandemic period }\end{array}$} \\
\hline & $\mathbf{n}$ & $\%$ & $\mathbf{n}$ & $\%$ \\
\hline Less cigarette consumption & 7 & 4 & 8 & 4.5 \\
\hline Less alcohol consumption & 1 & 0.6 & 2 & 1.1 \\
\hline Less water consumption & 20 & 11.3 & 25 & 14.1 \\
\hline Less tea and coffee consumption & 10 & 5.6 & 14 & 7.9 \\
\hline Disruption in sleep patterns & 40 & 22.6 & 43 & 24.3 \\
\hline Excessive sweating due to PPE & 43 & 24.3 & 42 & 23.7 \\
\hline The fact that wearing PPE makes it hard to see & 2 & 1.1 & 33 & 18.6 \\
\hline The fact that wearing PPE makes it difficult for me to breathe & 37 & 20.9 & 50 & 28.2 \\
\hline Stress experienced with fear of infection & 28 & 15.8 & 39 & 22 \\
\hline Stress experienced due to curfew & 18 & 10.2 & 25 & 14.1 \\
\hline Stress experienced by family members & 15 & 8.5 & 22 & 12.4 \\
\hline
\end{tabular}

PPE: Personal protective equipment.

Table 4. The effect of PPE usage frequency, working duration in COVID service, presence of visual defects, and change in daily water consumption on new and old headaches

\begin{tabular}{lcccc}
\hline Different variables that might have an effect on headache & $\begin{array}{c}\text { De novo } \\
\text { headache (n) }\end{array}$ & $\begin{array}{c}\text { p } \\
\text { headache (n) }\end{array}$ & p \\
\hline Working duration in the COVID service $<3$ months & 56 & 0.977 & 45 & 0.494 \\
Working duration in the COVID service $>3$ months & 10 & & 5 & \\
Daily mask wearing duration $<4 \mathrm{~h}$ & 4 & 0.5 & 1 & 0.04 \\
Daily mask wearing duration $>4 \mathrm{~h}$ & 62 & & 49 & \\
Monthly mask wearing duration $<15$ days & 15 & 0.525 & 14 & 0.573 \\
Monthly mask wearing duration $>15$ days & 51 & & 36 & \\
Daily goggles and/or face shield wearing duration $<4 \mathrm{~h}$ & 32 & 0.657 & 22 & 0.300 \\
Daily goggles and/or face shield wearing duration $>4 \mathrm{~h}$ & 34 & & 28 & \\
Monthly goggles and/or face shield wearing duration $<15$ days & 41 & 0.264 & 35 & 0.645 \\
Monthly goggles and/or face shield wearing duration $>15$ days & 25 & & 15 & \\
Daily mask+goggles/face shield+coverall wearing duration $<4 \mathrm{~h}$ & 29 & 0.886 & 18 & 0.56 \\
Daily mask+goggles/face shield+coverall wearing duration $>4 \mathrm{~h}$ & 37 & & 32 & \\
Monthly mask+goggles/face shield+coverall wearing duration $<15$ days & 43 & 0.018 & 39 & 0.366 \\
Monthly mask+goggles/face shield+coverall wearing duration $>15$ days & 23 & & 11 & \\
Having visual defects & 40 & 0.616 & 27 & 0.550 \\
Having no visual defects & 26 & & 23 & \\
Daily water consumption increased & 40 & 0.430 & 34 & 0.447 \\
Daily water consumption decreased & 15 & & 11 &
\end{tabular}

PPE: Personal protective equipment.

\section{Discussion}

The world met the COVID-19 disease that emerged in Wuhan, China, in late December 2019. Since then, humanity has been struggling with a pandemic, which is impossible to predict its termination. Undoubtedly, health-care professionals are at the fore- 
front of this struggle. COVID-19 disease is a viral infectious disease transmitted by the SARS-Cov-2 virus and has many different clinical presentations. Studies investigating how the disease spreads have shown that it is transmitted by droplets, and it is emphasized that especially the use of masks and distance are important in protection. ${ }^{[5]}$ However, it is not possible for the health personnel working in the frontline to approach the patient with distance. For this reason, the importance of PPE usage increases even more. As in the COVID-19 pandemic, the use of PPE is recommended during the care of patients with highly infectious diseases. ${ }^{[6]}$ Studies have been conducted to investigate the side effects of longterm use of PPE during epidemic diseases such as SARS and MERS, and side effects such as headache and skin reactions that adversely affect working performance have been determined. ${ }^{[3,7]}$ Our aim in this study is to determine the factors that cause headaches experienced by health-care professionals in the COVID-19 pandemic.

Long-term use of masks causes side effects such as headache, difficulty in breathing, skin problems, visual and hearing difficulties, and impaired thermal balance. The etiopathogenesis of headache caused by the use of masks has not been fully clarified. Two important factors are emphasized in etiopathogenesis. The first is the formation of hypoxia and hypercapnia and the other is external compression due to the use of PPE. In addition to these, insomnia, irregular eating, and emotional stress are accepted as etiological factors of headache experienced during the pandemic period. ${ }^{[3,8]}$

In a study investigating the effect of PPE use on de novo and existing headaches on 158 health care workers in Singapore, it was found that de novo headache developed in $81 \%$ of the participants. ${ }^{[8]}$ In the same study, the use of combined goggles and masks for more than $4 \mathrm{~h}$ a day was associated with the development of de novo headache and an increase in existing headache. All participants described their headaches bilaterally, and $87 \%$ reported a feeling of pressure and heaviness where the mask and goggles touched. About $72 \%$ of those who experienced headaches rated their pain as mild. About $31 \%$ of the participants used analgesics and preferred paracetamol firstly and NSAI medicines secondly. Migraine-like symptoms such as nausea/vomiting, photophobia, phonophobia, and movement sensitivity were observed in one quarter of the participants. About $53 \%$ of the participants indicated the use of PPE as a possible cause of headache. They attributed headaches to not only the use of PPE but also to cause that could disrupt internal and external hemostasis, such as insomnia, physical and emotional stress, irregular eating, and insufficient hydration caused by working conditions in the pandemic. These causes are also among the triggers of migraine..$^{[9]}$ In a similar survey study with 343 participants, $91.5 \%$ of the participants reported one or more side effects due to mask use, and the highest reported side effect was headache. About $71.4 \%$ of the participants in this survey did not have a known headache. In most of those, who had headache complaints, after the mask was removed, the pain complaint disappeared, while $28 \%$ of them received medical treatment. In addition, the participants of the survey stated that they made applications of frequent shift changes, neck massage at intervals, and hydration increase before the shift to prevent headache. ${ }^{[10]}$ In our study, 116 (65.5\%) participants experienced headaches during the pandemic period. Fifty $(28.2 \%)$ of the participants had previous headache complaints, and 66 (37.3\%) of them experienced de novo headaches. The majority of headaches were reported as throbbing, bilateral, and 5 or over. It often lasted for 1-4 h, 67 (37.9\%) were accompanied by light and sound sensitivity, 30 (16.9\%) were accompanied by migraine symptoms such as nausea and vomiting. Ninety-one $(52 \%)$ of those who experienced headache used medication. The first-choice medication was NSAI and the second preferred was paracetamol. In our study, the participants reported that medication usage, sleeping, PPE removal, drinking water, and being in a dark environment were most beneficial for headaches. Possible causes of headache are excessive sweating and difficulty in breathing due to the use of PPE, as well as disruption in sleep patterns, reduction in water consumption, and factors that cause stress. In fact, 111 (62.7\%) of the participants in the study reported an increase in water consumption when they wore PPE, but among the possible causes of headache, they reported the decrease in water consumption among the most 
common possible reasons. This is an indication that PPE use causes serious fluid loss, and it should not be overlooked that not only mechanical factors such as external compression but also dehydration may be an important factor in the etiopathogenesis of headache associated with PPE use, and care should be taken to ensure adequate hydration of health-care personnel while working in COVID services to prevent headache.

Ramirez-Moreno et al. ${ }^{[11]}$ carried out a study on 306 people to show whether there is a relationship between the appearance of de novo headache and the mask type and duration of use or not, and the effect of this headache on health care workers. De novo headache was detected in $52 \%$ of the participants. About $41 \%$ of those, who experienced headaches, had headaches such as migraine or tension type. Those who experienced headaches experienced an average of 12 days pain in a month, and their mean VAS score was also 6 . In this study, the biggest complaint was the decrease in working concentration with the effect of headache. In addition, female gender, smoking, use of masks, age, shift duration, and anxiety have been identified as independent risk factors for the development of "de novo" headache. In our study, we examined the causes that could be independent risk factors such as the duration of PPE use, hydration status, and accompanying visual defect. We determined that the use of masks longer than $4 \mathrm{~h}$ increased the severity and frequency of the old existing headache, and the use of combined PPE for $<15$ days in 1 month was effective in the development of de novo headache. As we mentioned in the limitations, the fact that reaching $59 \%$ of the study population may have prevented us from determining the risk factors. We attribute the development of de novo headache in combined PPE use for $<15$ days to the fact that dehydration may be higher in combined PPE use, and the inability of metabolism of health-care professionals to compensate for this situation in this short time. It cannot be expected that while using PPE, the health-care professionals work as long and efficiently as before the pandemic period. It is also a necessity to continue using PPE in this process. Therefore, one of the easiest solutions in the short term to reduce the side effects of PPE use seems to be arrangement of working durations.
It has also been shown that the use of PPE causes problems with vision. In the study conducted by Biçen and Ertürk, it was found that as the duration increases, complaints such as haze, inability to see clearly, and pain behind the eyes increased both in the use of surgical masks and in the use of FFP2. ${ }^{[12]}$ In the study conducted by Zuo et al., ${ }^{[13]}$ problems with vision were found in $6 \%$ of the participants, regardless of the type of mask used and the duration. In a study in which PPE ergonomics were questioned, it was found that the adaptation problem, which was $34 \%$ in protective goggles, increased to $62 \%$ in prescribed goggle wearers. ${ }^{[14]}$ In our study, $61(34.4 \%)$ of the participants were wearing goggles due to visual defects. Only $26(14.7 \%)$ of these participants did not use these goggles while using PPE. As a matter of fact, the participants who developed de novo headache stated that among the possible reasons, the use of PPE makes it difficult to see, with a rate of $18.6 \%$. To solve problems related to vision, masks with improved ergonomics are needed for use with goggles. Until reaching such masks, the most viable solution for now seems to be shortening the usage durations.

Although the headache associated with the use of PPE is a fact, the anxiety, depression, and personal characteristics of health-care professionals, who are in an extremely stressful work environment, should not be ignored, especially during the pandemic period, and studies should be carried out accordingly. There may be a misleading relationship between headache experienced in a work environment with such negative external stimuli and the use of PPE. ${ }^{[15]}$ Many recent studies have shown that the pandemic process significantly leads to depression, anxiety, and post-traumatic stress disorder in health care workers. ${ }^{[16]}$ Many factors such as the prevalence of infection among health-care personnel, excessive workload, and excessive working hours have been shown as the causes of negative psychological consequences in health care workers during pandemic periods. Significant stress, anxiety, depression, and insomnia are also observed in health care workers in charge of the COVID-19 pandemic. ${ }^{[17]}$ In our study, 147 (83.1\%) of the participants reported an increase in their stress and anxiety, and 128 (72.3\%) of them reported that their sleep patterns were disrupted. Apart from the stress caused by all these heavy working conditions, 
the concern of infecting their families is also an important stress factor for health-care professionals. The way to prevent this is social distance. However, it is a fact that social distancing deprives the individual of an important buffer against stress in such times. ${ }^{[18]}$ Many countries, including our country, apply some restrictions in social life to control viral transmission during the pandemic process. Although social isolation practices such as reducing mobility, closing many businesses and schools, and working at home instead of offices are very effective in preventing the spread of infection, they negatively affect people's mental health. ${ }^{[19]}$ As a matter of fact, 144 (81.4\%) of the participants stated that they could not do sports and exercise. In addition, they reported the negative effects of the stress they experienced due to restrictions and the stress experienced by other members of the family are among the possible causes of their headache. In these days when we cannot predict how long the pandemic process will continue, we think that it is necessary to carry out studies to improve the mental and social lives of health-care professionals.

In addition to all these, it should be kept in mind that one of the common non-respiratory symptoms of COVID-19 is headache. In the study investigating the spectrum of headache caused by COVID-19 in health-care professionals, $74 \%$ of the participants did not have a history of primary headache. Researchers found in this study that infection could trigger headache in those who do not have frequent headaches. ${ }^{[20]}$ For this reason, headache should not be considered solely as a result of PPE use or stress, and COVID-19 infection should definitely be investigated in new-onset persistent headache, especially for health-care professionals working in a high-risk group for infection. ${ }^{[21]}$

Our study had some limitations. First, only $59 \%$ of the study population was reached. This low rate may have prevented from reaching statistically significant results. Conducting the survey study under heavy working conditions during working hours may have affected the answers given to the survey questions. The effect of physical conditions such as temperature and humidity of the working environment was not questioned. Not questioning when headache started after wearing PPE and when it passed after removal, and not questioning the number of epi- sodes of pain is also a limitation. Whether the used N95 mask has an exhalation valve or not may also be effective on headache. Therefore, not questioning the existence of the valve and not questioning the relationship between the experienced headache and the COVID-19 infection are other limitations.

\section{Conclusion}

As a result, a substantial portion of health care workers struggling at the forefront of the pandemic process experiences headaches. In addition to the physical difficulties caused by the use of PPE on the development of headache, the effect of stress, anxiety, sleep disorders, and restrictions caused by the pandemic process should not be overlooked. We believe that more comfortable working conditions can be provided to health-care professionals with solutions such as reorganization of working hours, and more comprehensive studies should be carried out on the health problems and underlying causes experienced by health-care professionals during the pandemic process.

Conflict-of-interest issues regarding the authorship or article: None declared.

\section{Peer-rewiew: Externally peer-reviewed.}

\section{References}

1. Huang C, Wang Y, Li X, Ren L, Zhao J, Hu Y, et al. Clinical features of patients infected with 2019 novel coronavirus in Wuhan, China. Lancet 2020;395(10223):497-506. [CrossRef]

2. Wong JE, Leo YS, Tan CC. COVID-19 in Singapore-current experience: Critical global issues that require attention and action. JAMA 2020;323(13):1243-4. CrossRef.

3. Lim EC, Seet RC, Lee KH, Wilder-Smith EP, Chuah BY, Ong BK. Headaches and the N95 face-mask amongst healthcare providers. Acta Neurol Scand 2006;113(3):199-202. CrossRef]

4. Sharma TL. Common primary and secondary causes of headache in the elderly. Headache 2018;58(3):479-84.

5. Galbadage T, Peterson BM, Gunasekera RS. Does COVID-19 spread through droplets alone? Front Public Health 2020;8:163.

6. Smith JD, MacDougall CC, Johnstone J, Copes RA, Schwartz B, Garber GE. Effectiveness of N95 respirators versus surgical masks in protecting health care workers from acute respiratory infection: A systematic review and meta-analysis. CMAJ 2016;188(8):567-74. CrossRef]

7. Foo C, Goon ATJ, Leow YH, Goh CL. Adverse skin reactions to personal protective equipment against severe acute respiratory syndrome--a descriptive study in Singapore. Contact Dermatitis 2006;55(5):291-4. CrossRef]

8. Ong J, Bharatendu C, Goh Y, Tang JZ, Sooi KW, Tan YL, et 
al. Headaches associated with personal protective equipment - a cross-sectional study among frontline healthcare workers during COVID-19. Headache 2020;60(5):864-77.

9. Marmura MJ. Triggers, protectors, and predictors in episodic migraine. Curr Pain Headache Rep 2018;22(12):81.

10. Rosner E. Adverse effects of prolonged mask use among healthcare professionals during COVID-19. J Infect Dis Epidemiol 2020;6:130. [CrossRef]

11. Ramirez-Moreno JM, Ceberino D, Gonzalez-Plata A, Rebollo $\mathrm{B}$, Macías-Sedas $\mathrm{P}$, Ramchandani $\mathrm{RH}$, et al. Mask-associated De Novo Headache in Healthcare Workers during the COVID-19 Pandemic. New York: Medrxiv; 2020. [CrossRef]

12. Biçen Ç, Ertürk E. COVID-19 pandemi sürecinde sağlık çalışanlarında maske kullanımının etkilerinin değerlendirilmesi. Turk Stud 2020;15(6):205-18][CrossRef]

13. Zuo Y, Hua W, Luo Y, Li L. Skin reactions of N95 masks and medial masks among health-care personnel: A selfreport questionnaire survey in China. Contact Dermatitis 2020;83(2):145-7. CrossRef]

14. Hignett $S$, Welsh R, Banerjee J. Human factors issues of working in personal protective equipment during the $\mathrm{CO}$ VID-19 pandemic. Anaesthesia 2021;76(1):134-5. [CrossRef]

15. Magnavita N, Chirico F. Headaches, personal protective equipment, and psychosocial factors associated with COVID-19 pandemic. Headache 2020;60(7):1444-5. CrossRef]

16. Arnetz JE, Goetz CM, Sudan S, Arble E, Janisse J, Arnetz BB. Personal protective equipment and mental health symptoms among nurses during the COVID-19 pandemic. J Occup Environ Med 2020;62(11):892-7. CrossRef]

17. Spoorthy MS, Pratapa SK, Mahant S. Mental health problems faced by healthcare workers due to the COVID-19 pandemic-A review. Asian J Psychiatry 2020;51:102119.

18. Huremović D. Social distancing, quarantine, and isolation. In: Psychiatry of Pandemics: A Mental Health Response to Infection Outbreak. Cham: Springer; 2019. p. 85-94. [CrossRef]

19. Liu X, Kakade M, Fuller CJ, Fan B, Fang Y, Kong J, et al. Depression after exposure to stressful events: Lessons learned from the severe acute respiratory syndrome epidemic. Compr Psychiatry 2012;53(1):15-23. [CrossRef]

20. Porta-Etessam J, Matías-Guiu JA, González-García N, Iglesias PG, Santos-Bueso E, Arriola-Villalobos P, et al. Spectrum of headaches associated with SARS-CoV-2 infection: Study of healthcare professionals. Headache 2020;60(8):1697704.[CrossRef]

21. Bolay H, Gül A, Baykan B. COVID-19 is a Real Headache! Headache 2020;60(7):1415-21. 